\title{
Homozygosity for rs17775810 Minor Allele Associated With Reduced Mortality of COVID-19 in the UK Biobank Cohort
}

\author{
STEVEN LEHRER ${ }^{1}$ and PETER H. RHEINSTEIN ${ }^{2}$ \\ ${ }^{1}$ Department of Radiation Oncology, Icahn School of Medicine at Mount Sinai, New York, NY, U.S.A.; \\ ${ }^{2}$ Severn Health Solutions, Severna Park, MD, U.S.A.
}

\begin{abstract}
Background/Aim: Adult outpatients with symptomatic COVID-19 treated with fluvoxamine, compared with placebo, had a lower likelihood of clinical deterioration over 15 days. Fluvoxamine strongly binds to the sigma-1 receptor $(S 1 R)$ that regulates inflammation by inhibiting the production of cytokines, believed to be responsible for severe COVID-19. We evaluated the S1R locus on chr 9p13.3 in subjects tested positive for SARS-CoV-2. We focused on SNP rs 17775810 that has been previously identified by examining loss-of-function mutations in the S1R gene associated with distal hereditary motor neuropathy. Patients and Methods: We utilized UK Biobank (UKB) data. Data processing was performed on Minerva, a Linux mainframe with Centos 7.6, at the Icahn School of Medicine at Mount Sinai. Results: The effect of rs 17775810 genotype on survival was significant ( $p=0.036,2$ tailed Fisher exact test). The minor allele homozygotes (TT) had the lowest death rate $(0 \%)$, whereas the non-TT genotypes (i.e. CT and CC) had the highest death rate (16.2\%). Conclusion: The rs 17775810 analysis corroborates the favorable effect of fluvoxamine on COVID19 survival.
\end{abstract}

In a preliminary study, adult outpatients with symptomatic COVID-19 treated with fluvoxamine, compared with placebo, had a lower likelihood of clinical deterioration over 15 days. Fluvoxamine strongly binds to the sigma-1 receptor (S1R) that regulates inflammation by inhibiting the production of cytokines, believed to be responsible for severe COVID-19 (1). The S1R receptor is a ubiquitously

This article is freely accessible online.

Correspondence to: Dr. Steven Lehrer, Box 1236 Radiation Oncology, Mount Sinai Medical Center, 1 Gustave L. Levy Place, New York 10029, U.S.A. Tel: +1 2127657132, e-mail: steven.lehrer@mssm.edu

Key Words: S1r, allele, fluvoxamine, COVID-19, motor neuropathy. expressed endoplasmic reticulum (ER) chaperone protein located mainly at the ER membrane rather than predominantly on the plasma membrane of cells. The S1R receptor is expressed in many types of cells, not only immune cells, and can detach from the ER membrane and function in the ER lumen, chaperoning other proteins through the ER.

\section{Patients and Methods}

We utilized data from the UK Biobank (UKB). The UKB databases consist of data obtained from $>500,000$ community volunteers between 40-70 years of age at baseline (2006-2010), residing close to 22 assessment centers in the UK, Scotland and Wales. Baseline assessments on the database include demographics, the lifestyle of the subjects and the disease history of the subjects, with links available leading to electronic medical records. The UKB application for the present study was approved as UKB project 57245 (S.L. and P.H.R.) (2).

To investigate the relationship between S1R and COVID-19, we evaluated the S1R locus on chr 9p13.3 in subjects tested positive for SARS-CoV-2. We analysed the SNP rs17775810. This SNP has previously identified loss-of-function mutations in the S1R gene causing distal hereditary motor neuropathy (3) linked to an area including two SNPs: rs17775810, analyzed here, and one other not in UKB, which covered an area of $7.9 \mathrm{Mb}$. rs 17775810 has a single nucleotide variation, $\mathrm{C}>\mathrm{T}$, with minor allele $(\mathrm{T})$ frequency $=0.21$.

Data processing was performed on Minerva, a Linux mainframe with Centos 7.6, at the Icahn School of Medicine at Mount Sinai. We used PLINK, a whole-genome association analysis toolset, to process the UKB chromosome 9 files, and the UK Biobank Data Parser (ukbb parser), a python-based package that allows easy interfacing with the large UKB dataset (4).

\section{Results}

We evaluated the association of the rs17775810 genotypes with survival of COVID-19 patients and designated the major rs 17775810 allele as $\mathrm{C}$ and the minor allele as $\mathrm{T}$. We analyzed data from 688 UKB subjects with laboratory confirmed COVID-19, 49\% female, $51 \%$ male. The mean 
age was $54 \pm 9.2($ mean \pm SD). One hundred eight $(16 \%)$ had died of COVID-19. Among the subjects, $83 \%$ were white British, 3\% were Irish, 3\% were of any other white background, 2\% were African, 2\% were Caribbean, 7\% were of other ethnicity.

COVID-19 survival according to the different genotypes (TT homozygote versus non-TT) is shown in Table I. The effect of each genotype on survival was significant ( $p=0.036$, 2 tailed Fisher exact test). The TT homozygotes had the lowest death rate $(0 \%)$, whereas the non-TT genotypes (i.e. CT and CC) had the highest death rate (16.2\%).

COVID-19 survival according to the rs17775810 genotype (TT versus $\mathrm{CT}$ and $\mathrm{CC}$ ) is shown in Table II. The TT homozygotes had the lowest death rate $(0 \%, p=0.020$, likelihood ratio).

\section{Discussion}

Genome-wide association studies have found multiple genes and loci that increase the risk of respiratory failure in COVID-19 (5). One locus on chromosome 3p21.31 contains 6 genes involved in inflammation (SLC6A20, LZTFL1, CCR9, FYCO1, CXCR6, and XCR1) (5).

The ABO gene, chr 9q34.2, which determines blood type, may affect disease severity. Corrected for age and sex, a higher risk for respiratory failure was found among persons with blood group A than among patients with other blood groups, and a protective effect for blood group $\mathrm{O}$ as compared with the other blood groups (5). However, this result has not been reproduced. A UK study of 2200 COVID19 patients found no relationship of ABO blood type with disease severity (6). A Danish study identified ABO blood group as a risk factor for SARS-CoV-2 infection but not for hospitalization or death from COVID-19 (7).

We examined the association of rs17775810 genotypes with the survival of COVID-19 patients. We found that individuals homozygous for the rs17775810 minor allele (TT) have a lower death rate. This result is consistent with another study on SARS-CoV that examined the effect of a polymorphism in CLEC4M, which encodes L-SIGN, a SARS-CoV binding receptor (8). It was shown that homozygosity for CLEC4M tandem repeats played a protective role in SARS coronavirus infection. This effect was not observed in heterozygotes (9).

It has been shown that fluvoxamine can prevent clinical deterioration of COVID-19 patients (1). It is not known whether this effect of fluvoxamine is due to actions on immune cells versus other types of cells. There are in fact several different hypothesized mechanisms by which fluvoxamine might act. Some involve S1R receptor binding, but others do not $(8,10-14)$.

Our rs17775810 analysis suggests that the favorable effect of fluvoxamine on survival, as reported by Lenze et al. (1), may be mediated through $\mathrm{S} 1 \mathrm{R}$ receptor.
Table I. COVID-19 patient survival according to the rs 17775810 genotype (TT versus non-TT) in 688 UKB subjects. The effect of genotype on survival was significant ( $p=0.036,2$ tailed Fisher exact test). The TT homozygotes had the lowest death rate (0\%), whereas the non-TT genotypes (i.e. CT and CC) had the highest death rate (16.2\%).

\begin{tabular}{lccc}
\hline Genotype & Alive & Died & $\%$ Died \\
\hline Non-TT & 557 & 108 & 16.2 \\
TT & 23 & 0 & 0 \\
\hline
\end{tabular}

Table II. COVID-19 patient survival according to the rs 17775810 genotype (TT versus CT and CC) in 688 UKB subjects ( $p=0.020$, likelihood ratio).

\begin{tabular}{lccc}
\hline Genotype & Alive & Died & $\%$ Died \\
\hline CC & 361 & 66 & 15.5 \\
CT & 196 & 42 & 17.6 \\
TT & 23 & 0 & 0 \\
\hline
\end{tabular}

A weakness of our study is that rs 17775810 , a common SNP, has no known functional significance and is not within the S1R gene or within any other known gene. S1R starts at chr9p $34,634,722$ bp, ends at $34,637,809 \mathrm{bp}$; rs17775810 is at $30,504,350$. We were able to examine one SNP within S1R, rs11559048, but the minor allele frequency (0.002) was too low to produce meaningful statistics. There are four other SNPs within S1R (15), but the UKB had no data on them, nor did we have whole exome sequencing data. Further studies are warranted.

\section{Conflicts of Interest}

The Authors report no conflicts of interest in relation to this study.

\section{Authors' Contributions}

Dr. Lehrer and Dr. Rheinstein contributed equally to the conception, writing, and data analysis of this study.

\section{Acknowledgements}

This work was supported in part through the computational resources and staff expertise provided by the Scientific Computing at the Icahn School of Medicine at Mount Sinai, NY, U.S.A. Research reported in this paper was also supported by the Office of Research Infrastructure of the National Institutes of Health under award numbers S10OD018522 and S10OD026880. The content is solely the responsibility of the authors and does not necessarily represent the official views of the National Institutes of Health. 


\section{References}

1 Lenze EJ, Mattar C, Zorumski CF, Stevens A, Schweiger J, Nicol GE, Miller JP, Yang L, Yingling M, Avidan MS and Reiersen AM: Fluvoxamine vs placebo and clinical deterioration in outpatients with symptomatic covid-19: A randomized clinical trial. JAMA 324(22): 2292-2300, 2020. PMID: 33180097. DOI: $10.1001 /$ jama.2020.22760

2 Atkins JL, Masoli JA, Delgado J, Pilling LC, Kuo C-L, Kuchel GA and Melzer D: Preexisting comorbidities predicting covid19 and mortality in the uk biobank community cohort. J Gerontol A Biol Sci Med Sci 75(11): 2224-2230, 2020. PMID: 32687551. DOI: $10.1093 /$ gerona/glaa183

3 Gregianin E, Pallafacchina G, Zanin S, Crippa V, Rusmini P, Poletti A, Fang M, Li Z, Diano L, Petrucci A, Lispi L, Cavallaro T, Fabrizi GM, Muglia M, Boaretto F, Vettori A, Rizzuto R, Mostacciuolo ML and Vazza G: Loss-of-function mutations in the sigmar 1 gene cause distal hereditary motor neuropathy by impairing er-mitochondria tethering and ca2+ signalling. Hum Mol Genet 25(17): 3741-3753, 2016. PMID: 27402882. DOI: $10.1093 / \mathrm{hmg} / \mathrm{ddw} 220$

4 Zhu A, Salminen LE,Thompson PM and Jahanshad N: The uk biobank data parser: A tool with built in and customizable filters for brain studies. Organization for Human Brain Mapping. Rome, Italy, June 9-13, 2019.

5 Severe Covid GG, Ellinghaus D, Degenhardt F, Bujanda L, Buti M, Albillos A, Invernizzi P, Fernandez J, Prati D, Baselli G, Asselta R, Grimsrud MM, Milani C, Aziz F, Kassens J, May S, Wendorff M, Wienbrandt L, Uellendahl-Werth F, Zheng T, Yi X, de Pablo R, Chercoles AG, Palom A, Garcia-Fernandez AE, Rodriguez-Frias F, Zanella A, Bandera A, Protti A, Aghemo A, Lleo A, Biondi A, Caballero-Garralda A, Gori A, Tanck A, Carreras Nolla A, Latiano A, Fracanzani AL, Peschuck A, Julia A, Pesenti A, Voza A, Jimenez D, Mateos B, Nafria Jimenez B, Quereda C, Paccapelo C, Gassner C, Angelini C, Cea C, Solier A, Pestana D, Muniz-Diaz E, Sandoval E, Paraboschi EM, Navas E, Garcia Sanchez F, Ceriotti F, Martinelli-Boneschi F, Peyvandi F, Blasi F, Tellez L, Blanco-Grau A, Hemmrich-Stanisak G, Grasselli G, Costantino G, Cardamone G, Foti G, Aneli S, Kurihara H, ElAbd H, My I, Galvan-Femenia I, Martin J, Erdmann J, Ferrusquia-Acosta J, Garcia-Etxebarria K, Izquierdo-Sanchez L, Bettini LR, Sumoy L, Terranova L, Moreira L, Santoro L, Scudeller L, Mesonero F, Roade L, Ruhlemann MC, Schaefer M, Carrabba M, Riveiro-Barciela M, Figuera Basso ME, Valsecchi MG, Hernandez-Tejero M, Acosta-Herrera M, D'Angio M, Baldini M, Cazzaniga M, Schulzky M, Cecconi M, Wittig M, Ciccarelli M, Rodriguez-Gandia M, Bocciolone M, Miozzo M, Montano N, Braun N, Sacchi N, Martinez N, Ozer O, Palmieri O, Faverio P, Preatoni P, Bonfanti P, Omodei P, Tentorio P, Castro P, Rodrigues PM, Blandino Ortiz A, de Cid R, Ferrer R, Gualtierotti R, Nieto R, Goerg S, Badalamenti S, Marsal S, Matullo G, Pelusi S, Juzenas S, Aliberti S, Monzani V, Moreno V, Wesse T, Lenz TL, Pumarola T, Rimoldi V, Bosari S, Albrecht W, Peter W, RomeroGomez M, D'Amato M, Duga S, Banales JM, Hov JR, Folseraas T, Valenti L, Franke A and Karlsen TH: Genomewide association study of severe covid-19 with respiratory failure. N Engl J Med 383(16): 1522-1534, 2020. PMID: 32558485. DOI: 10.1056/NEJMoa2020283

6 Kaiser J: Found: Genes that sway the course of the coronavirus. Science 370(6514): 275-276, 2020. PMID: 33060342. DOI: $10.1126 /$ science. 370.6514 .275
7 Barnkob MB, Pottegård A, Støvring H, Haunstrup TM, Homburg K, Larsen R, Hansen MB, Titlestad K, Aagaard B, Møller BK and Barington T: Reduced prevalence of sars-cov-2 infection in abo blood group o. Blood Advances 4(20): 49904993, 2020. DOI: 10.1182/bloodadvances.2020002657

8 Yesilkaya UH, Balcioglu YH and Sahin S: Reissuing the sigma receptors for sars-cov-2. J Clin Neurosci 80: 72-73, 2020. PMID: 33099370. DOI: 10.1016/j.jocn.2020.08.014

9 Chan VS, Chan KY, Chen Y, Poon LL, Cheung AN, Zheng B, Chan KH, Mak W, Ngan HY, Xu X, Screaton G, Tam PK, Austyn JM, Chan LC, Yip SP, Peiris M, Khoo US and Lin CL: Homozygous 1-sign (clec4m) plays a protective role in sars coronavirus infection. Nat Genet 38(1): 38-46, 2006. PMID: 16369534. DOI: $10.1038 / n g 1698$

10 Rosen DA, Seki SM, Fernandez-Castaneda A, Beiter RM, Eccles JD, Woodfolk JA and Gaultier A: Modulation of the sigma-1 receptor-ire1 pathway is beneficial in preclinical models of inflammation and sepsis. Sci Transl Med 11(478): eaau5266, 2019. PMID: 30728287. DOI: 10.1126/scitranslmed aau5266

11 Gordon DE, Jang GM, Bouhaddou M, Xu J, Obernier K, White KM, O'Meara MJ, Rezelj VV, Guo JZ, Swaney DL, Tummino TA, Huttenhain R, Kaake RM, Richards AL, Tutuncuoglu B, Foussard H, Batra J, Haas K, Modak M, Kim M, Haas P, Polacco BJ, Braberg H, Fabius JM, Eckhardt M, Soucheray M, Bennett MJ, Cakir M, McGregor MJ, Li Q, Meyer B, Roesch F, Vallet T, Mac Kain A, Miorin L, Moreno E, Naing ZZC, Zhou Y, Peng S, Shi Y, Zhang Z, Shen W, Kirby IT, Melnyk JE, Chorba JS, Lou K, Dai SA, Barrio-Hernandez I, Memon D, Hernandez-Armenta C, Lyu J, Mathy CJP, Perica T, Pilla KB, Ganesan SJ, Saltzberg DJ, Rakesh R, Liu X, Rosenthal SB, Calviello L, Venkataramanan S, Liboy-Lugo J, Lin Y, Huang XP, Liu Y, Wankowicz SA, Bohn M, Safari M, Ugur FS, Koh C, Savar NS, Tran QD, Shengjuler D, Fletcher SJ, O'Neal MC, Cai Y, Chang JCJ, Broadhurst DJ, Klippsten S, Sharp PP, Wenzell NA, Kuzuoglu-Ozturk D, Wang HY, Trenker R, Young JM, Cavero DA, Hiatt J, Roth TL, Rathore U, Subramanian A, Noack J, Hubert M, Stroud RM, Frankel AD, Rosenberg OS, Verba KA, Agard DA, Ott M, Emerman M, Jura N, von Zastrow M, Verdin E, Ashworth A, Schwartz O, d'Enfert C, Mukherjee S, Jacobson M, Malik HS, Fujimori DG, Ideker T, Craik CS, Floor SN, Fraser JS, Gross JD, Sali A, Roth BL, Ruggero D, Taunton J, Kortemme T, Beltrao P, Vignuzzi M, Garcia-Sastre A, Shokat KM, Shoichet BK and Krogan NJ: A sars-cov-2 protein interaction map reveals targets for drug repurposing. Nature 583(7816): 459-468, 2020. PMID: 32353859. DOI: 10.1038/s41586-020-2286-9

12 Gordon DE, Hiatt J, Bouhaddou M, Rezelj VV, Ulferts S, Braberg H, Jureka AS, Obernier K, Guo JZ, Batra J, Kaake RM, Weckstein AR, Owens TW, Gupta M, Pourmal S, Titus EW, Cakir M, Soucheray M, McGregor M, Cakir Z, Jang G, O’Meara MJ, Tummino TA, Zhang Z, Foussard H, Rojc A, Zhou Y, Kuchenov D, Huttenhain R, Xu J, Eckhardt M, Swaney DL, Fabius JM, Ummadi M, Tutuncuoglu B, Rathore U, Modak M, Haas P, Haas KM, Naing ZZC, Pulido EH, Shi Y, BarrioHernandez I, Memon D, Petsalaki E, Dunham A, Marrero MC, Burke D, Koh C, Vallet T, Silvas JA, Azumaya CM, Billesbolle C, Brilot AF, Campbell MG, Diallo A, Dickinson MS, Diwanji D, Herrera N, Hoppe N, Kratochvil HT, Liu Y, Merz GE, Moritz M, Nguyen HC, Nowotny C, Puchades C, Rizo AN, SchulzeGahmen U, Smith AM, Sun M, Young ID, Zhao J, Asarnow D, Biel J, Bowen A, Braxton JR, Chen J, Chio CM, Chio US, 
Deshpande I, Doan L, Faust B, Flores S, Jin M, Kim K, Lam VL, Li F, Li J, Li YL, Li Y, Liu X, Lo M, Lopez KE, Melo AA, Moss FR $3^{\text {rd }}$, Nguyen P, Paulino J, Pawar KI, Peters JK, Pospiech TH, Jr., Safari M, Sangwan S, Schaefer K, Thomas PV, Thwin AC, Trenker R, Tse E, Tsui TKM, Wang F, Whitis N, Yu Z, Zhang K, Zhang Y, Zhou F, Saltzberg D, Consortium QSB, Hodder AJ, Shun-Shion AS, Williams DM, White KM, Rosales R, Kehrer T, Miorin L, Moreno E, Patel AH, Rihn S, Khalid MM, Vallejo-Gracia A, Fozouni P, Simoneau CR, Roth TL, Wu D, Karim MA, Ghoussaini M, Dunham I, Berardi F, Weigang S, Chazal M, Park J, Logue J, McGrath M, Weston S, Haupt R, Hastie CJ, Elliott M, Brown F, Burness KA, Reid E, Dorward M, Johnson C, Wilkinson SG, Geyer A, Giesel DM, Baillie C, Raggett S, Leech H, Toth R, Goodman N, Keough KC, Lind AL, Zoonomia C, Klesh RJ, Hemphill KR, Carlson-Stevermer J, Oki J, Holden K, Maures T, Pollard KS, Sali A, Agard DA, Cheng Y, Fraser JS, Frost A, Jura N, Kortemme T, Manglik A, Southworth DR, Stroud RM, Alessi DR, Davies P, Frieman MB, Ideker T, Abate C, Jouvenet N, Kochs G, Shoichet B, Ott M, Palmarini M, Shokat KM, Garcia-Sastre A, Rassen JA, Grosse R, Rosenberg OS, Verba KA, Basler CF, Vignuzzi M, Peden AA, Beltrao P and Krogan NJ: Comparative host-coronavirus protein interaction networks reveal pan-viral disease mechanisms. Science 370(6521): eabe9403, 2020. PMID: 33060197. DOI: 10.1126/science.abe 9403
13 Pandey P, Prasad K, Prakash A and Kumar V: Insights into the biased activity of dextromethorphan and haloperidol towards sars-cov-2 nsp6: In silico binding mechanistic analysis. J Mol Med (Berl) 98(12): 1659-1673, 2020. PMID: 32965508. DOI: 10.1007/s00109-020-01980-1

14 Nicol GE, Karp JF, Reiersen AM, Zorumski CF and Lenze EJ: "What were you before the war?" Repurposing psychiatry during the covid-19 pandemic. J Clin Psychiatry 81(3): 20com13373, 2020. PMID: 32271506. DOI: 10.4088/JCP.20com13373

15 Lovkvist H, Jonsson AC, Luthman H, Jood K, Jern C, Wieloch $\mathrm{T}$ and Lindgren A: Variations in apolipoprotein $\mathrm{d}$ and sigma nonopioid intracellular receptor 1 genes with relation to risk, severity and outcome of ischemic stroke. BMC Neurol 14: 191, 2014. PMID: 25261976. DOI: 10.1186/s12883-014-0191-2

Received December 14, 2020

Revised December 31, 2020

Accepted January 14, 2021 